DOI: $10.19195 / 0137-1134.109 .15$

\title{
SABINA GRABOWSKA
}

Uniwersytet Rzeszowski

\section{REGULACJE PRAWNE ODPOWIEDZIALNOŚCI KONSTYTUCYJNEJ PREZYDENTA FEDERALNEGO NIEMIEC}

Konstytucja Niemiec w art. 61 ust. $1^{1}$ dopuszcza oskarżenie Prezydenta Federalnego o umyślne naruszenie Konstytucji lub też ustawy federalnej² ${ }^{2}$ Jest to wąskie rozumienie deliktu konstytucyjnego, za popełnienie którego prezydent może zostać pociągnięty do odpowiedzialności konstytucyjnej przed Federalnym Trybunałem Konstytucyjnym. Ponadto w Niemczech przepisy zawężają przedmiot odpowiedzialności konstytucyjnej prezydenta, ponieważ oskarżenie może dotyczyć działania lub zaniechania popełnionego tylko z winy umyślnej ${ }^{3}$. Tym samym ustrojodawcy wyłączyli z zakresu odpowiedzialności konstytucyjnej wszystkie działania i zaniechania, które prezydent popełnił nieumyślnie, nie określając, na czym ma polegać naruszenie ustawy oraz czy chodzi tylko o ciężkie, czy o jakiekolwiek naruszenie konstytucji. Tematem niniejszego opracowania będą przepisy prawne regulujące postępowanie w sprawie odpowiedzialności konstytucyjnej Prezydenta Federalnego Niemiec.

${ }^{1}$ Ustawa Zasadnicza Republiki Federalnej Niemiec z dnia 23 maja 1949 r., http://libr.sejm. gov.pl/tek01/txt/konst/niemcy2011.html (dostęp: 15.10.2016).

2 R. Balicki, Formy odpowiedzialności konstytucyjnej w Republice Federalnej Niemiec, [w:] Formy odpowiedzialności konstytucyjnej w państwach europejskich, red. S. Grabowska, R. Grabowski, Toruń 2010, s. 207-209; E. Zwierzchowski, Republika Federalna Niemiec, [w:] Systemy polityczne rozwiniętych krajów kapitalistycznych, red. A. Jamroz, Warszawa 1989, s. 267; E. Gdulewicz, Ustrój polityczny Republiki Federalnej Niemiec, [w:] Ustroje państw współczesnych, t. 1, red. W. Skrzydło, Lublin 2010, s. 121.

${ }^{3}$ P. Czarny, Republika Federalna Niemiec, [w:] Ustrój Unii Europejskiej i ustroje państw członkowskich, red. P. Sarnecki, Warszawa 2007, s. 297. 
Ryszard Balicki zwraca uwagę, że w doktrynie niemieckiego prawa konstytucyjnego istnieje pogląd dopuszczający możliwość wszczęcia postępowania w sprawie odpowiedzialności konstytucyjnej Prezydenta Federalnego także w wypadku naruszenia tzw. reguł zwyczajowego prawa konstytucyjnego, uznanych przez Federalny Trybunał Konstytucyjny (dalej: FTK) za niepisane reguły prawa konstytucyjnego, które wiążą wszystkie organy państwowe ${ }^{4}$. Ponadto doktryna niemiecka stoi na stanowisku, że nie każde naruszenie normy konstytucyjnej lub ustawowej powinno być przesłanką do wszczęcia postępowania w sprawie odpowiedzialności konstytucyjnej ${ }^{5}$. Dla jej wszczęcia konieczne jest, aby działanie lub zaniechanie prezydenta naruszało istotne przepisy dotyczące zasad ustroju politycznego ${ }^{6}$. R. Herzog stwierdza, że należy to robić z uwzględnieniem zasady proporcjonalności, czyli podejmowane działania powinny być adekwatne do sytuacji ${ }^{7}$.

Ponadto ustrojodawca niemiecki rozciągnął odpowiedzialność konstytucyjną nie tylko na przepisy konstytucyjne, lecz także na przepisy ustaw federalnych, czyli takich, które zostały uchwalone zgodnie z konstytucyjnymi regułami tworzenia prawa na szczeblu federacji: przez Bundestag z uczestnictwem Bundesratu, przez Komisję Wspólną oraz zgodnie z procedurą stanu konieczności ustawodawczej.

Na specyfikę odpowiedzialności konstytucyjnej, oprócz jej charakterystyki podmiotowo-przedmiotowej, składa się również odmienne postępowanie. W ramach procedury pociągnięcia do odpowiedzialności konstytucyjnej wyróżnia się następujące etapy. Postępowanie rozpoczyna złożenie przez grupę inicjatorów wniosku w sprawie popelnienia deliktu konstytucyjnego przez prezydenta oraz przeprowadzenie postępowania wstępnego w parlamencie (przez komisję parlamentarną bądź przez izbę). Następnie odbywa się debata na posiedzeniu plenarnym izby lub — jeśli w państwie funkcjonuje parlament dwuizbowy — na wspólnym posiedzeniu obu izb. W dalszej kolejności podejmowana jest uchwała o postawieniu w stan oskarżenia prezydenta przed Federalnym Trybunałem Konstytucyjnym. Poparcie wniosku o pociągnięcie prezydenta do odpowiedzialności konstytucyjnej przez większość

${ }^{4}$ R. Balicki, op. cit., s. 210-211.

5 Por. M. Bożek, Instytucja Prezydenta Republiki Federalnej Niemiec, Warszawa 2007, s. 253. O pojęciu niepisanych reguł prawa konstytucyjnego zob. B. Banaszak, Porównawcze prawo konstytucyjne wspótczesnych państw demokratycznych, Warszawa 2007, s. 123.

${ }^{6}$ R. Herzog, Schrifttumshinweise zu Art. 61, [w:] Grundgesetz. Kommentar, red. T. Maunz, G. Dürig, München 2009, Rdnr. 20.

7 M. Bożek, op. cit., s. 256.

8 Por. też: T. Maunz, komentarz do $\$ 49$, [w:] T. Maunz et al., Bundesverfassungsgerichtsgesetz. Kommentar, München 2008; R. Balicki, Ustroje państw wspótczesnych, Wrocław 2003, s. 90. 
głosujących skutkuje przekazaniem sprawy do FTK, gdzie przeprowadzane jest postępowanie i badane są zarzuty stawiane prezydentowi. W analizowanych rozwiązaniach ustrojowych ma to miejsce podczas postępowania przygotowawczego, a następnie rozprawy głównej w FTK. Po zakończeniu postępowania trybunał wydaje orzeczenie $\mathrm{w}$ sprawie popełnienia przez prezydenta deliktu konstytucyjnego.

Postępowanie w sprawie odpowiedzialności konstytucyjnej prezydenta reguluje art. 61 Ustawy Zasadniczej. Przepisy konstytucyjne nie regulują precyzyjnie problematyki odpowiedzialności konstytucyjnej prezydenta, przeciwnie, stanowią raczej regulacje ramowe. Szczegółowe unormowanie postępowania w sprawie odpowiedzialności konstytucyjnej prezydenta pozostawiono regulacjom ustawowym.

Uzupełnieniem oraz rozszerzeniem regulacji konstytucyjnych dotyczących odpowiedzialności konstytucyjnej prezydenta są akty prawne regulujące funkcjonowanie parlamentów oraz regulujące kompetencje i organizację FTK.

W Niemczech, gdzie parlament jest dwuizbowy, postępowanie w sprawie deliktu konstytucyjnego prezydenta regulują akty prawne obu izb parlamentu, czyli regulamin Bundestagu ${ }^{9}$ i regulamin Rady Federalnej (Bundesratu) ${ }^{10}$. Ponadto postępowanie $\mathrm{w}$ sprawie pociągnięcia prezydenta do odpowiedzialności konstytucyjnej przed FTK uregulowane zostało w ustawie o Federalnym Trybunale Konstytucyjnym ${ }^{11}$.

Rozproszenie regulacji z tej samej dziedziny w wielu aktach prawnych może prowadzić do powielania tych samych przepisów. W efekcie może dojść do powstania nieścisłości lub wręcz kolizji norm prawnych, podczas gdy z założenia ustawa ma doprecyzować regulacje konstytucyjne i umożliwić ich stosowanie, w tym wypadku poprzez uregulowanie postępowania w sprawie odpowiedzialności konstytucyjnej prezydenta.

Wiele problemów może też stwarzać zbyt lakoniczne uregulowanie procedury egzekwowania odpowiedzialności konstytucyjnej, czego przykładem mogą być przepisy niemieckie ${ }^{12}$. Przepisy te są tak ogólnikowe, że można zaryzykować twierdzenie, iż etap postępowania w parlamencie nie został uregulowany i konieczne jest posiłkowanie się przepisami ogólnymi normującymi działalność komisji, postępowanie $\mathrm{z}$ wnioskiem oraz debatę $\mathrm{w}$ izbie. Uważam, że nie jest to właściwe, gdyż postępowanie w tak istotniej sprawie, jak postawienie w stan oskarżenia głowy państwa, powinno zostać uregulowane precyzyjnie.

9 Regulamin Niemieckiego Bundestagu z dnia 28 stycznia 1952 r. (BGB1 II nr 5, s. 389, z dnia 3 marca 1952 r.), http://www.bundestag.de/dokumente/rechtsgrundlagen/go_btg/index.html (dostęp: 15.10.2016).

10 Regulamin Rady Federalnej (Bundesratu) z dnia 15 lipca 1966 r. (BGB1 I nr 31 s. 437, z dnia 27 lipca 1966 r.), http://www.bundesrat.de/EN/funktionen-en/go-en/go-en-node.html (dostęp: 15.10.2016).

11 Ustawa z dnia 12 marca 1951 r. o Federalnym Trybunale Konstytucyjnym (BGBl I nr 17, s. 243, z dnia 16 kwietnia 1951 r.), http://www.gesetze-im-internet.de/bundesrecht/bverfgg/gesamt. pdf (dostęp: 15.10.2016).

12 Grundgesetz. Kommentar, s. 1904. 
Do wszczęcia postępowania w sprawie odpowiedzialności konstytucyjnej prezydenta niezbędny jest wniosek w tej sprawie.

Przepisy niemieckie nie precyzują, kto może złożyć wniosek o pociągnięcie Prezydenta Federalnego do odpowiedzialności konstytucyjnej. Dlatego też, moim zdaniem, w takim przypadku należy per analogie uznać za właściwe przepisy regulujące zasady postępowania związane ze złożeniem jakiegokolwiek wniosku w Bundestagu ${ }^{13}$ lub w Bundesracie ${ }^{14}$. Może tego dokonać grupa składającą się z jednej czwartej członków Bundestagu lub z jednej czwartej członków Bundesratu ${ }^{15}$. Wniosek taki powinien zostać złożony w formie pisemnej oraz, choć przepisy tego bezpośrednio nie precyzują ${ }^{16}$, zawierać zarzuty stawiane Prezydentowi Federalnemu oraz uzasadnienie ${ }^{17}$. Przepisy konstytucyjne oraz inne akty prawne nie regulują postępowania z wnioskiem o pociągnięcie Prezydenta Federalnego do odpowiedzialności konstytucyjnej w parlamencie ${ }^{18}$. Następnie może on zostać skierowany do komisji bądź też izba może powołać komisję nadzwyczajną w tej sprawie ${ }^{19}$.

Przepisy niemieckie nie zawierają informacji o tym, kto, kiedy i czy w ogóle powiadamia prezydenta o fakcie złożenia wniosku w sprawie popełnienia przez niego deliktu konstytucyjnego. Zasadnym wydaje się stwierdzenie, iż obowiązek ten spoczywa na przewodniczącym izby, do której wpłynął wniosek.

W Niemczech przepisy nie przewidują obligatoryjnego przekazania wniosku do komisji celem jego weryfikacji. Nie zawierają również żadnych regulacji postępowania w parlamencie z wnioskiem o pociągnięcie Prezydenta Federalnego do odpowiedzialności za delikt konstytucyjny ${ }^{20}$. Jednak moim zdaniem, jeśli taki wniosek zostanie złożony, nie może on zostać zbagatelizowany i powinien trafić pod obrady komisji, która zbada jego zasadność i przedstawi na posiedzeniu plenarnym swoje stanowisko $\mathrm{w}$ tej sprawie ${ }^{21}$.

13 Art. 44 Konstytucji Niemiec oraz $\S 56$ regulaminu Bundestagu.

$14 \S 42$ ust. 1 regulaminu Bundesratu.

15 Art. 61 ust. 1 Konstytucji Niemiec. W wypadku Bundesratu chodzi o wniosek krajów, które w sumie mają co najmniej o jedną czwartą głosów w Bundesracie.

$16 \S 76$ regulaminu Bundestagu.

17 Szerzej o wniosku zob. R. Herzog, op. cit., Rdnr 38.

18 W. Heun, The Constitution of Germany. A Contextual Analysis, Oxford-Portland Oregon 2011, s. 100-126.

19 Grundgesetz. Kommentar, s. 1904.

${ }^{20}$ C. Krehl, Anklageerhebung, [w:] Bundesverfassungsgerichtsgesetz: Mitarbeiterkommentar und Handbuch. Heidelberger Kommentar, red. D.C. Umbach, T. Clemens, F.W. Dollinger, Hüthig Jehle Rehm 2005, s. 771.

${ }^{21}$ Na temat pracy komisji parlamentarnych zob. A. Szmyt, Stanowienie ustaw w RFN, Gdańsk 1993, s. 116-134; P. Czarny, Bundesrat, między niemiecka tradycja a europejska przyszłościa, Warszawa 2000, s. 86-87; H. Widder, Rada Narodowa, [w:] Parlament Republiki Austrii, red. H. Schambeck, przeł. B. Banaszak, Warszawa 1997, s. 66-69; I. Kathrein, Rada Federalna, [w:] Parlament Republiki Austrii, s. 113-116. 
W Niemczech do podjęcia uchwały w sprawie pociągnięcia Prezydenta Federalnego do odpowiedzialności konstytucyjnej wystarczy podjęcie uchwały $\mathrm{w}$ tej sprawie przez jedną z izb parlamentu ${ }^{22}$. Dla ważności uchwały wymagana jest większość co najmniej dwóch trzecich głosów członków Bundestagu lub dwóch trzecich głosów członków Bundesratu ${ }^{23}$. Przed głosowaniem odbywa się jedno czytanie projektu ${ }^{24}$. Uchwała izby parlamentu przedkładana jest $\mathrm{w}$ formie aktu oskarżenia Federalnemu Trybunałowi Konstytucyjnemu. Uchwała taka może wpłynąć do trybunału najpóźniej w terminie trzech miesięcy od powzięcia wiadomości o zaistniałych faktach mogących stać się podstawą do złożenia wniosku o pociągnięcie Prezydenta Federalnego do odpowiedzialności konstytucyjnej25. Jest to termin o charakterze prekluzyjnym (zawitym).

Akt oskarżenia jest sporządzany przez przewodniczącego na podstawie przyjętej uchwały ${ }^{26}$. Musi on określać działania lub zaniechania, których dopuścił się Prezydent Federalny, oraz wskazywać naruszone postanowienia ustawy zasadniczej lub ustawy federalnej, a także precyzować wnioski dowodowe, które mają zostać przeprowadzone w toku postępowania przez Trybunałem Konstytucyjnym. Ponadto akt oskarżenia powinien zawierać informację, iż uchwała w przedmiotowej sprawie została przyjęta konstytucyjnie wymaganą większością ${ }^{27}$. W uchwale o postawieniu Prezydenta Federalnego w stan oskarżenia izba parlamentu, zgodnie z art. 61 ust. 1 ustawy zasadniczej, wyznacza swojego pełnomocnika, który będzie reprezentował izbę w toku dalszego postępowania. Pełnomocnik nie musi się rekrutować spośród członków izby. Akt oskarżenia jest przekazywany Federalnemu Trybunałowi Konstytucyjnemu w terminie miesiąca od uchwalenia ${ }^{28}$.

Do czasu ogłoszenia wyroku przez Federalny Trybunał Konstytucyjny organ, który wszczął postępowanie o pociągnięcie Prezydenta Federalnego do odpowiedzialności konstytucyjnej, może wycofać akt oskarżenia. W tym celu wymagane jest przyjęcie większością ustawowej liczby posłów przez Bundestag lub większością ogólnej liczby głosów przez Bundesrat stosownej uchwały. Jest ona przekazywana Federalnemu Trybunałowi Konstytucyjnemu przez przewodniczącego danej izby. Wycofanie oskarżenia jest bezskuteczne, jeżeli w ciągu miesiąca swój sprzeciw wyrazi Prezydent Federalny ${ }^{29}$.

22 B. Banaszak, System konstytucyjny Niemiec, Warszawa 2005, s. 88.

23 E. Zwierzchowski, Rada Federalna Republiki Federalnej Niemiec, [w:] Izby drugie parlamentu, red. E. Zwierzchowski, Białystok 1996, s. 203.

$24 \S 78$ ust. 1 regulaminu Bundestagu.

$25 \S 49-50$ ust. 1 ustawy o Federalnym Trybunale Konstytucyjnym Niemiec.

26 A. Mirska, Prezydent Federalny Republiki Federalnej Niemiec, [w:] Prezydent w państwach wspótczesnych, red. J. Osiński, Warszawa 2009, s. 467.

$27 \S 49$ ust. 3 ustawy o Federalnym Trybunale Konstytucyjnym Niemiec.

${ }^{28}$ R. Herzog, op. cit., Rdnr. 38, 42.

$29 \S 52$ ustawy o Federalnym Trybunale Konstytucyjnym Niemiec. 
Uznanie budzą rozwiązania niemieckie, gdzie przesłanką zakończenia postępowania nie może być ani dymisja Prezydenta Federalnego, ani upływ kadencji Prezydenta Federalnego, ani upływ kadencji Bundestagu, ani jego rozwiązanie. Powaga deliktu konstytucyjnego, a także prewencyjny charakter odpowiedzialności konstytucyjnej — zarówno w zakresie prewencji szczególnej, jak i ogólnej — wymagają, aby wszczęte zgodnie z prawem postępowanie zakończyło się wydaniem orzeczenia w sprawie popełnienia deliktu konstytucyjnego przez Prezydenta Federalnego.

\section{V}

W Niemczech organem uprawnionym do orzekania w przedmiocie odpowiedzialności konstytucyjnej Prezydenta Federalnego jest Federalny Trybunał Konstytucyjny ${ }^{30}$. Składa się on z 16 sędziów wybieranych po połowie przez Bundesrat i Bundestag na dwunastoletnią kadencję. Są oni podzieleni na dwa senaty, których kompetencje zostały szczegółowo określone w ustawie o Federalnym Trybunale Konstytucyjnym $^{31}$. W sprawach związanych z odpowiedzialnością konstytucyjną Prezydenta Federalnego właściwy jest senat drugi. Do ważności uchwał senatu wymagana jest obecność co najmniej sześciu sędziów. Jeśli senat stanie się niezdolny do procedowania, przewodniczący zarządza losowanie spośród sędziów $\mathrm{z}$ pozostałego senatu $\mathrm{w}$ celu uzupełnienia składu ${ }^{32}$.

Procedowanie w sprawie odpowiedzialności konstytucyjnej przez FTK rozpoczyna się $\mathrm{w}$ momencie złożenia $\mathrm{w}$ trybunale aktu oskarżenia, uchwalonego przez parlament. Przed rozpoczęciem postępowania wstępnego przewodniczący FTK przesyła kopię aktu oskarżenia wraz z uzasadnieniem oraz dowodami do prezydenta, aby ten mógł ustosunkować się do zarzutów.

W Niemczech Federalny Trybunał może, w celu przygotowania rozprawy głównej, zarządzić przeprowadzenie dochodzenia wstępnego. Sędzią śledczym jest jeden z sędziów pierwszego senatu, który nie jest właściwy do orzekania w sprawach z zakresu odpowiedzialności konstytucyjnej Prezydenta Federalnego. Dochodzenie wstępne jest obligatoryjne w wypadku, gdy zażąda tego Prezydent Federalny lub przedstawiciel oskarżenia ${ }^{33}$.

Po przeprowadzeniu dochodzenia wstępnego przewodniczący senatu drugiego zaprasza Prezydenta Federalnego do udziału rozprawie. Jeśli Prezydent Federalny nie weźmie udziału w rozprawie z nieusprawiedliwionych powodów, odbędzie się ona bez jego udziału. Rozprawa rozpoczyna się od przedstawienia Prezydentowi

30 K.A. Wojtaszczyk, Wspótczesne systemy polityczne, Warszawa 2000, s. 84-86.

31 L. Garlicki, Federalny Trybunat Konstytucyjny w Republice Federalnej Niemiec, [w:] Sady konstytucyjne w Europie. Austria, Francja, Niemcy, Włochy, t. 1, red. J. Trzciński, Warszawa 1996, s. 138.

32 Art. 14-15 ustawy o Federalnym Trybunale Konstytucyjnym Niemiec.

$33 \S 54$ ustawy o Federalnym Trybunale Konstytucyjnym Niemiec. 
Federalnemu przez pełnomocnika wyznaczonego przez jedną z izb parlamentu zarzutów sformułowanych w akcie oskarżenia. Następnie głos zabiera Prezydent Federalny i przedstawia swoje stanowisko w sprawie, po czym przeprowadzane jest postępowanie dowodowe. Tę część postępowania kończy wystąpienie pełnomocnika izby parlamentu, a jako ostatni głos zabiera Prezydent Federalny. Po wysłuchaniu stron, świadków oraz po analizie dowodów Trybunał Konstytucyjny wydaje wyrok w sprawie umyślnego naruszenia ustawy zasadniczej lub ustawy federalnej, przy czym decyzję podejmuje większością dwóch trzecich głosów członków senatu orzekającego. Trybunał określa precyzyjnie, na czym polegało naruszenie prawa przez oskarżonego - o ile stwierdzono, że do niego doszło. Egzemplarze wyroku oraz jego uzasadnienie zostają przekazane Bundestagowi, Bundesratowi oraz rządowi federalnemu ${ }^{34}$.

Analiza postępowania głównego przed FTK nasuwa kilka wniosków. Za zasadne należy uznać regulacje, które przewidują przeprowadzenie postępowania przygotowawczego. Dzięki temu rozprawa główna może przebiec sprawnie, bez konieczności odraczania posiedzenia ze względu na braki formalne w akcie oskarżenia. Jednakże regulacje niemieckie, które powierzają funkcję sędziego śledczego sędziemu z innego senatu niż właściwy do orzekania w sprawie odpowiedzialności konstytucyjnej Prezydenta Federalnego, uniemożliwiają tym samym jego udział w dalszym postępowaniu. Moim zdaniem nie jest to rozwiązanie właściwe, gdyż ten właśnie sędzia po zbadaniu dostarczonych do Federalnego Trybunału Konstytucyjnego dokumentów jest osobą, która najlepiej orientuje się w sprawie, i jego sugestie czy też opinie mogłyby przyczynić się do sprawniejszego przebiegu postępowania.

\section{VI}

Gdy niemiecki Federalny Trybunał Konstytucyjny uzna Prezydenta Federalnego za winnego dopuszczenia się umyślnego naruszenia ustawy zasadniczej, może orzec złożenie go $\mathrm{z}$ urzędu ${ }^{35}$. Istotne $\mathrm{z}$ prawnego punktu widzenia jest użycie określenia „może”. Tak więc teoretycznie możliwa jest sytuacja, w której Trybunał stwierdzi jedynie winę prezydenta i odstąpi od wymierzenia kary. Rozumowanie takie może budzić zrozumiałe kontrowersje, ponieważ trudno wyobrazić sobie sytuację, w której trybunał, orzekając o umyślnym naruszeniu przez Prezydenta Federalnego przepisów ustawy zasadniczej lub ustawy federalnej, odstąpi od wymierzenia kary. Ponadto, jak słusznie zauważa R. Balicki, stanowisko takie nie byłoby zrozumiane przez opinię publiczną, gdyż doniosła waga stawianych zarzutów, potwierdzona orzeczeniem najważniejszego organu sądowego, musi

$34 \S 55-\S 57$ ustawy o Federalnym Trybunale Konstytucyjnym Niemiec.

35 Art. 61 ust. 2 Konstytucji Niemiec, $\S 56$ ustawy o Federalnym Trybunale Konstytucyjnym Niemiec. 
w konsekwencji prowadzić do złożenia z urzędu ${ }^{36}$. Oprócz stwierdzenia winy Prezydenta Federalnego, Federalny Trybunał Konstytucyjny w swoim wyroku musi określić, czy może on pobierać świadczenia emerytalne przysługujące byłemu prezydentowi ${ }^{37}$, albowiem Trybunał może orzec o utracie świadczenia emerytalnego w całości lub w określonej części.

Postępowanie w sprawie odpowiedzialności konstytucyjnej prezydenta może się wiązać z koniecznością podjęcia dodatkowych działań, takich jak: zawieszenie w sprawowaniu urzędu, zastępstwo prezydenta oraz przedterminowe wybory na urząd prezydenta. Od wniesienia aktu oskarżenia aż do chwili wydania wyroku niemiecki Federalny Trybunał Konstytucyjny może wydać zarządzenie tymczasowe o zaistnieniu przeszkody uniemożliwiającej Prezydentowi Federalnemu sprawowanie urzędu ${ }^{38}$.

Kolejna kwestia związana z postępowaniem w sprawie popełnienia przez prezydenta deliktu konstytucyjnego to zastępstwo prezydenta $\mathrm{w}$ trakcie zawieszenia w sprawowaniu urzędu oraz po złożeniu go $\mathrm{z}$ urzędu. Przepisy niemieckie powierzają zastępstwo prezydenta przewodniczącemu izby drugiej parlamentu. W Niemczech jest to Przewodniczący Bundesratu ${ }^{39}$.

Po ogłoszeniu wyroku uznającego prezydenta winnym popełnienia deliktu konstytucyjnego i złożeniu go z urzędu zarządzane są wybory na opróżniony urząd. W Niemczech przeprowadza się wybory w ciągu trzydziestu dni od wydania wyroku przez Federalny Trybunat ${ }^{40}$.

Fakultatywność zawieszenia prezydenta w sprawowaniu urzędu można określić jako rozwiązanie o charakterze fasadowym. W sytuacji, w której podstawą wniesienia oskarżenia przeciwko prezydentowi są zarzuty naruszenia przepisów konstytucji, regulujących np. zasady ustroju politycznego, trudno wykazać zasadność sprawowania urzędu do czasu podjęcia rozstrzygnięcia w sprawie. Ponadto w trakcie postępowania aktywność prezydenta z pewnością byłaby ukierunkowania na udowodnienie swojej niewinności, a nie na wykonywanie obowiązków konstytucyjnych.

36 R. Balicki, op. cit., s. 214.

37 Art. 5 ustawy o świadczeniach emerytalnych Prezydenta Federalnego Niemiec.

38 Art. 61 ust. 2 Konstytucji Niemiec; $§ 53$ ustawy o Federalnym Trybunale Konstytucyjnym Niemiec. Por. szerzej: R. Herzog, op. cit., Rdnr. 66.

39 Art. 57 Konstytucji Niemiec. Funkcję przewodniczącego Bundesratu pełnią — kolejno Premierzy rządów krajów związkowych, por. R. Balicki, op. cit., s. 76-77.

40 Art. 54 ust. 4 Konstytucji Niemiec. Zob. K.A. Wojtaszczyk, Bundestag i Bundesrat w Republice Federalnej Niemiec, Warszawa 1993, s. 27; R. Balicki, Prawo wyborcze na urzad prezydenta w Niemczech, [w:] Prawo wyborcze na urząd prezydenta w państwach europejskich, red. S. Grabowska, R. Grabowski, Warszawa 2007, s. 296. 


\section{LEGAL REGULATIONS OF CONSTITUTIONAL RESPONSIBILITY OF THE FEDERAL PRESIDENT OF GERMANY}

\section{Summary}

The text is an analysis of the German legal regulations concerning the constitutional responsibility of the President. Federal President of Germany for committing a constitutional delict is responsible before the Federal Constitutional Court. The proposal in this regard may submit a group of parliamentarians and parliament puts indictment. If the Federal Constitutional Court decides the merits of allegations made in the indictment, the president shall be deposited with the office. 